\title{
Effects of Short-term Fasting on Selected Physiological Functions in Adult Male and Female Japanese Quail
}

\author{
D. LAMOŠOVÁ ${ }^{1}$, M. MÁČAJOVÁ ${ }^{1}$, M. ZEMAN ${ }^{2}$ \\ ${ }^{1}$ Institute of Animal Biochemistry and Genetics, Slovak Academy of Sciences, \\ Ivanka pri Dunaji \\ ${ }^{2}$ Department of Animal Physiology and Ethology Comenius University, Bratislava, \\ Slovak Republic \\ Received July 21, 2003 \\ Accepted February 11, 2004
}

Abstract

Lamošová D., M. Máčajová, M. Zeman: Effects of Short-term Fasting on Selected Physiological Functions in Adult Male and Female Japanese Quail. Acta Vet. Brno 2004, 73: 9-16.

Effects of a short-term fasting $(0,12,24$ and $48 \mathrm{~h})$ on plasma leptin and alkaline phosphatase concentrations, selected parameters of lipid metabolism, protein and glucose were studied in both sexes of adult Japanese quail. Fasting caused a reduction of glucose concentration in liver of females $(P<0.05)$ and males $(P<0.05-0.001)$ as well as reduction of total lipids in plasma of females $(P<0.05-0.001)$ and liver of females $(P<0.05)$ and males $(P<0.05-0.01)$. Triacylglycerols decreased in plasma of females $(P<0.05$ and 0.01$)$ and in liver of females $(P<$ 0.05 and 0.001$)$ and males $(P<0.05$ and 0.01$)$. Significant effect of sex was proved by a decrease of liver weight $(P<0.05-0.01)$, total lipid concentration in plasma $(P<0.05$ and 0.001$)$ and in liver $(P<0.05)$. Significant differences between sexes were also observed in concentration of triacylglycerols in plasma and liver $(P<0.01-0.001)$. The sex differences were found also in the activity of alkaline phosphatase in plasma $(P<0.05-0.001)$. Whereas no changes were found in males, in females the activity of alkaline phosphatase increased significantly after all fasting period $(P<0.05$ - 0.001). Plasma leptin concentrations, egg laying, testes weight and protein content in plasma, liver and breast muscle were not affected by short-term starvation. We can conclude that short-term fasting affected mainly the lipid metabolism of adult birds.

Sex differences, alkaline phosphatase, glucose, leptin, lipids metabolism, protein

Food intake is influenced by genetic background and the endocrine status of the organism and, in turn, food intake can influence most of its physiological functions. It is known that deprivation of energy supply induces a delay in the development of some vital functions in mammals: puberty starts later, the reproductive age prolonges, ageing starts later and deterioration of immunity and health is delayed (Banks and Lebel 2002). Changes in these vital functions are induced and accompanied by endocrine changes. Most information about these adaptive mechanisms is derived from studies in mammals (S a udek and Felig 1976; Goodman and Ruderman 1980). In birds, it has been found that their response to prolonged fasting can be divided into three phases. The first phase, which lasts a few days, is characterized by a rapid decrease in body weight and high fat mobilization. The second phase is longer and characterized by a slow and steady decline in the rate of body weight loss and the third phase is a critical period characterized by an abrupt increase in the rate of body loss and increased protein catabolism (Sartori et al. 1995). We focused on the first phase of fasting and analyzed the response of adult males and females of Japanese quail that have different fat stores.

Present research of starvation in vertebrates is connected with studying of leptin that serves as a mediator of the adaptation to fasting. In humans, serum leptin concentrations as well as plasma levels of metabolic parameters (glucose, cholesterol, lipids) change rapidly 
after short-term starvation (B oden et al. 1996). In birds, the role of leptin concentration related to fasting was studied less (Sato et al. 2000; Kobayashi and Ishii 2002). The research of starvation in birds has been focused mainly on young animals and usually on one sex. Two weeks of food deprivation (about $23.5 \mathrm{~h}$ of food deprivation daily) caused a shift from lipogenesis to lipolysis, increased fatty acid turnover and reduction in protein anabolism in 2-4-week-old male broiler chickens (B u y se et al. 2002). In contrast to fasting in mammals, plasma concentrations of glucose in geese were maintained at high levels throughout fasting (Le Maho et al. 1981). A higher resistance of plasma glucose levels to food deprivation has also been observed in other avian species, including quail (Didier et al. 1983; Sartori et al. 1995).

We used Japanese quail for our experiments because it is a suitable model to study the metabolic responses of birds naturally non-adapted to fasting. These birds of small size are easy to handle in laboratory, can have shorter metabolic phases of fasting and their pattern of response to starvation is similar to that observed in larger birds (Sartori et al. 1995). Since consequences of starvation may be age- and sex-dependent, the purpose of this study was to compare the effects of a short-term fasting on selected metabolic parameters in adult Japanese quail (Coturnix japonica) of both sexes.

Materials and Methods

Animals

Adult (8-week-old) Japanese quail of both sexes used in experiments came from our breeding colony. They were housed in individual cages in a climate-controlled room with daylight. Water and food (feeding mash: $21 \%$ crude protein and $12 \mathrm{MJ} / \mathrm{kg}$ of metabolizable energy) were available ad libitum. Before the experiment, birds of both sexes were weighed and divided into four groups $(n=5)$ to have same mean body weight in each group (females: $136.9 \pm 4.4 \mathrm{~g}$ and males $123.6 \pm 3.3 \mathrm{~g}$ ). Food was taken away for 12,24 or $48 \mathrm{~h}$ from all quail at the same time $(08.00 \mathrm{~h}=0$ time $)$. During the fast, water was available ad libitum. Quail were decapitated immediately after the fasting period. Blood samples were collected into heparinized tubes. Plasma was stored at $-20{ }^{\circ} \mathrm{C}$ until assayed for hormone leptin and metabolic parameters. The weights of liver, testes and spleen were recorded. The body weight of birds was determined before and after starvation and egg laying (number and weight of eggs) was recorded daily at the same time of day.

Methods

Concentrations of leptin in plasma were measured by a mouse leptin radioimmunoassay kit (Linco Research Inc, MO, USA). A $\gamma$-counter JNG 402 (Slovakia) was used for the measurement of radioactivity. Concentrations of glucose, total cholesterol, triacylglycerols, total lipids and the activity of alkaline phosphatase in plasma and in the liver were assayed by commercially available kits (Bio-la-test, Lachema, Czech Republic). The protein content was quantified by method of Lowry et al. (1951) with bovine serum albumin as a standard.

The data are presented as mean \pm S.E.M. The effects of fasting time and sex were estimated with two-way analysis of variance (ANOVA). Differences between means were determined by the least significant differences (LSD) test. We used the program STATISTICA.

\section{Results and Discussion}

Food deprivation lasting for $12 \mathrm{~h}$ led to a reduction of body mass in males $(8.2 \%)$ and females $(3.5 \%)$, respectively (Table 1$)$. Body weight of males starved for $24 \mathrm{~h}$ was decreased about $11.6 \%$ in comparison with the initial one, whereas in females body weight was not changed after next $12 \mathrm{~h}$ starvation $(3.7 \%)$. In females, a decline of body weight represents $17.3 \%$ (during the second $24 \mathrm{~h}$ about $14.2 \%$ ) and in males $14 \%$ (during the second $24 \mathrm{~h}$ about $2.7 \%$ ) of initial body mass. Analysis of variation demonstrates general significant effect of sex in body weight $(P<0.05)$.

We found a decreasing trend of liver weight in parallel with body weight decline during fasting but significant differences $(P<0.05-0.01)$ were found only between sexes in all fasting periods. Weights of testes and spleen were not affected by fasting (Table 1).

Both adipose tissue (Lepkovsky 1983) and liver (Lacy et al. 1986) are believed to be important peripheral sites involved in food intake, body weight and lipid regulation in birds 
Table 1

Weights of body, liver, testes and spleen in adult Japanese quail after $0,12,24$ and $48 \mathrm{~h}$ fasting

\begin{tabular}{|llccc|}
\hline $\begin{array}{c}\text { Time of } \\
\text { fasting }\end{array}$ & $\begin{array}{c}\text { Body } \\
(\mathrm{g})\end{array}$ & $\begin{array}{c}\text { Liver } \\
(\mathrm{g})\end{array}$ & $\begin{array}{c}\text { Testes } \\
(\mathrm{g})\end{array}$ & $\begin{array}{c}\text { Spleen } \\
(\mathrm{g})\end{array}$ \\
\hline $0 \mathrm{~h}$ & $136.9 \pm 4.4$ & $4.32 \pm 1.02$ & & $0.045 \pm 0.02$ \\
$12 \mathrm{~h}$ & $132.1 \pm 8.2$ & $3.74 \pm 0.18$ & & $0.065 \pm 0.01$ \\
$24 \mathrm{~h}$ & $131.9 \pm 3.8$ & $3.46 \pm 0.32$ & & $0.081 \pm 0.01$ \\
$48 \mathrm{~h}$ & $113.2 \pm 13.7$ & $3.27 \pm 1.53$ & & $0.037 \pm 0.02$ \\
& & & & \\
$0 \mathrm{~h}$ & $123.6 \pm 3.3$ & $2.47 \pm 0.22 \mathrm{a}$ & $3.53 \pm 0.23$ & $0.043 \pm 0.01$ \\
$12 \mathrm{~h}$ & $113.5 \pm 13.4$ & $1.76 \pm 0.19 \mathrm{aa}$ & $3.61 \pm 0.40$ & $0.035 \pm 0.01$ \\
$24 \mathrm{~h}$ & $109.3 \pm 1.7$ & $1.78 \pm 0.03 \mathrm{a}$ & $3.86 \pm 0.45$ & $0.031 \pm 0.01$ \\
$48 \mathrm{~h}$ & $106.3 \pm 4.1$ & $1.58 \pm 0.28 \mathrm{a}$ & $3.07 \pm 0.39$ & $0.027 \pm 0.02$ \\
\hline
\end{tabular}

Data are means \pm S.E.M. $\mathrm{n}=5$; aa $P<0.01$, a $P<0.05$ males vs females in corresponding time of fasting.

(Denbow et al. 2000). Animals use their lipid stores to compensate for deficit of energy and loss of body weight induced by periods of food shortage (B oswell et al. 2002). The signal between the peripheral lipid stores and the central nervous system is exerted by the hormon leptin. It circulates in the blood at levels correlated with body fat mass and controls food intake and energy homeostasis (Ashwell et al. 1999). However, plasma leptin levels in food deprived quail of both sexes (evaluated by ANOVA) were not changed significantly in comparison with samples taken before fasting (Table 2). These data are in contrast with results obtained in mammals (Saladin et al. 1995). These authors showed that weight loss results in decreased leptin levels whereas weight gain significantly increases circulating leptin concentrations. S ato et al. (2000) also detected significantly decreased plasma leptin levels in fasted young chickens compared to the fed ones. It is possible that leptin levels were not completely measured by the mouse kit in present experiments because leptin levels were substantially lower than those measured by chicken leptin-specific radioimmunoassay (commercially not available) in young chicken (Dridi et al. 2000). Leptin showed a trend of higher levels in females as compared with males what corresponds with results obtained in mammals (Maffei et al. 1995).

Short-term fasting affected mainly lipid metabolism of quail. Concentrations of total lipids in plasma of females decreased gradually with time of fasting. A significant decrease was found after $12(P<0.05), 24(P<0.01)$ and $48 \mathrm{~h}(P<0.001)$ in females but not in males (Fig. 1A). There were determined significant differences between sexes already on start of experiment $(0 \mathrm{~h}$ of fasting, $P<0.001)$ and after $12 \mathrm{~h}$ of fasting $(P<0.05)$. Then, concentration of total lipids in plasma of females were equivalent to males. Content of total lipids in the liver of males (Fig.1B) decreased significantly after 12, 24 as well after $48 \mathrm{~h}$ of fasting $(P<0.05-0.01)$. Our results in males are in agreement with data of Sartori et al. (1995) who found a decreased lipid content in the liver after the first $24 \mathrm{~h}$ of fasting in males of Japanese quail, while concentrations returned to the control range after $4 \mathrm{~d}$ of fasting. In females, hepatic total lipids were significantly decreased only after $24 \mathrm{~h}$ of fasting $(P<0.05)$. Generally, the concentration of hepatic lipids was higher in females compared with males (after 12 and $24 \mathrm{~h}$ of fasting $P<0.05$ ).

Concentrations of triacylglycerols (TAG) in plasma exhibited a gradual decrease with prolonged time of starvation (after $24 \mathrm{~h} P<0.05$ and after $48 \mathrm{~h} P<0.01$ ) in females (Fig.1C). There was found out the trend of decrease in plasma TAG concentration owing to fasting in males. The gender differences were observed already from the experiment start ( 0 and $12 \mathrm{~h} P<0.001 ; 24 \mathrm{~h} P<0.01)$. Content of triacylglycerols in the liver (Fig. $1 \mathrm{D})$ of fasting females and males was significantly decreased after all experimental periods $(P<$ 0.05-0.001). Our data suggest that food deprivation causes a increased lipolysis 
Table 2

Concentration of leptin and glucose in plasma and concentration of glucose and cholesterol in the liver of adult Japanese quail after 0, 12, 24 and $48 \mathrm{~h}$ fasting

\begin{tabular}{|c|c|c|c|c|c|}
\hline $\begin{array}{l}\text { Time of } \\
\text { fasting }\end{array}$ & $\begin{array}{c}\text { Leptin } \\
\text { in plasma } \\
(\mathrm{ng} / \mathrm{ml})\end{array}$ & $\begin{array}{c}\text { Cholesterol } \\
\text { in plasma } \\
(\mathrm{mmol} / \mathrm{l})\end{array}$ & $\begin{array}{c}\text { Cholesterol } \\
\text { in the liver } \\
(\mathrm{mmol} / \mathrm{l})\end{array}$ & $\begin{array}{c}\text { Glucose } \\
\text { in plasma } \\
(\mathrm{mmol} / \mathrm{l})\end{array}$ & $\begin{array}{l}\text { Glucose } \\
\text { in the liver } \\
(\mathrm{mmol} / \mathrm{l})\end{array}$ \\
\hline $90 \mathrm{~h}$ & $\begin{array}{l}0.233 \pm \\
0.03\end{array}$ & $3.24 \pm 0.24$ & $2.24 \pm 0.66$ & $21.22 \pm 0.15$ & $17.93 \pm 3.64$ \\
\hline $12 \mathrm{~h}$ & $\begin{array}{l}0.276 \pm \\
0.07\end{array}$ & $3.52 \pm 0.40$ & $1.81 \pm 0.44$ & $16.36 \pm 0.66$ & $8.32 \pm 0.78^{*}$ \\
\hline $24 \mathrm{~h}$ & $\begin{array}{l}0.221 \pm \\
0.03\end{array}$ & $3.73 \pm 0.31$ & $1.35 \pm 0.25$ & $18.64 \pm 0.94$ & $7.50 \pm 1.65^{*}$ \\
\hline $48 \mathrm{~h}$ & $\begin{array}{l}0.455 \pm \\
0.21\end{array}$ & $4.03 \pm 0.34$ & $1.26 \pm 0.28$ & $23.44 \pm 6.56$ & $10.83 \pm 1.69$ \\
\hline$\delta 0 \mathrm{~h}$ & $\begin{array}{l}0.172 \pm \\
0.04\end{array}$ & $4.06 \pm 0.31$ & $1.55 \pm 0.12$ & $20.65 \pm 1.06$ & $23.33 \pm 6.06$ \\
\hline $12 \mathrm{~h}$ & $\begin{array}{l}0.212 \pm \\
0.10\end{array}$ & $5.78 \pm 1.86$ & $1.10 \pm 0.04$ & $17.69 \pm 0.95$ & $5.65 \pm 0.15^{* * *}$ \\
\hline $24 \mathrm{~h}$ & $\begin{array}{l}0.242 \pm \\
0.02\end{array}$ & $6.14 \pm 1.43$ & $1.11 \pm 0.23$ & $15.73 \pm 1.43$ & $7.57 \pm 1.57 * *$ \\
\hline $48 \mathrm{~h}$ & $\begin{array}{l}0.251 \pm \\
0.01\end{array}$ & $5.39 \pm 0.64$ & $1.06 \pm 0.07$ & $18.56 \pm 1.86$ & $13.33 \pm 3.32 *$ \\
\hline
\end{tabular}

Data are means \pm S.E.M., $\mathrm{n}=5,{ }^{*} * * P<0.001, * * P<0.01, * P<0.05$ vs 0 time of fasting.

simultaneously with lowered lipogenesis during the first $48 \mathrm{~h}$. The content of triacylglycerols in the liver of females was significantly higher compared to males after 0 and $12 \mathrm{~h}$ of fasting $(P<0.01-0.001)$. The results validate the fact that males of Japanese quail have smaller fat stores and they could be more affected by fasting. The sex differences in lipid metabolism of adult birds are probably connected with egg laying. In our experiment the egg laying was not significantly influenced by short-term fasting (neither number nor weight of eggs). Before experiment eggs laying was in range $66.7-100 \%$. On day of fasting start the eggs laying was $83.3 \%$ and mean of egg weight in quail selected for experiment was $9.74 \mathrm{~g}$. After $12 \mathrm{~h}$ of fasting eggs laying was $77.8 \%(9.71 \mathrm{~g})$, after $24 \mathrm{~h}$ : $72.2 \%(9.87 \mathrm{~g})$ and after $48 \mathrm{~h}: 100 \%$ (9.14 g).

Although there were no significant differences between sexes in single fasting length groups, ANOVA proved overall effect of gender on both the content of cholesterol in plasma $(P<0.01)$ and liver $(P<0.05)$. Concentrations of cholesterol in plasma were lower (about $20 \%$ ) and in the liver higher (about 30\%) in females compared with males. The decrease of lipids concentration in the liver of fasting quail resulted in trend of decrease cholesterol concentration in the liver of both sexes. Plasma cholesterol concentrations (Table 2) expressed a trend to higher levels with time of starvation in both sexes, suggesting secretion of cholesterol mainly from the liver of fasting quail. Our results indicated that the liver has a capability to control steady state plasma levels of cholesterol which is consistent with results in mammals (Marino et al. 2002).

In our experiment protein anabolism and catabolism remained well balanced because the protein content in the plasma, liver and breast muscle were not changed during the shortterm starvation (Fig. 2 A, B, C). These results are in agreement with the theory of three phases of fasting, where in the first phase (2-3 d) the fat stores of the organism decrease but proteins are not extensively used. Two weeks of food deprivation caused a reduction in protein anabolism in 2-week-old male broiler chickens (B uyse et al. 2002).

Glucose concentration in chicken is tightly regulated by insulin and glucagon, and 

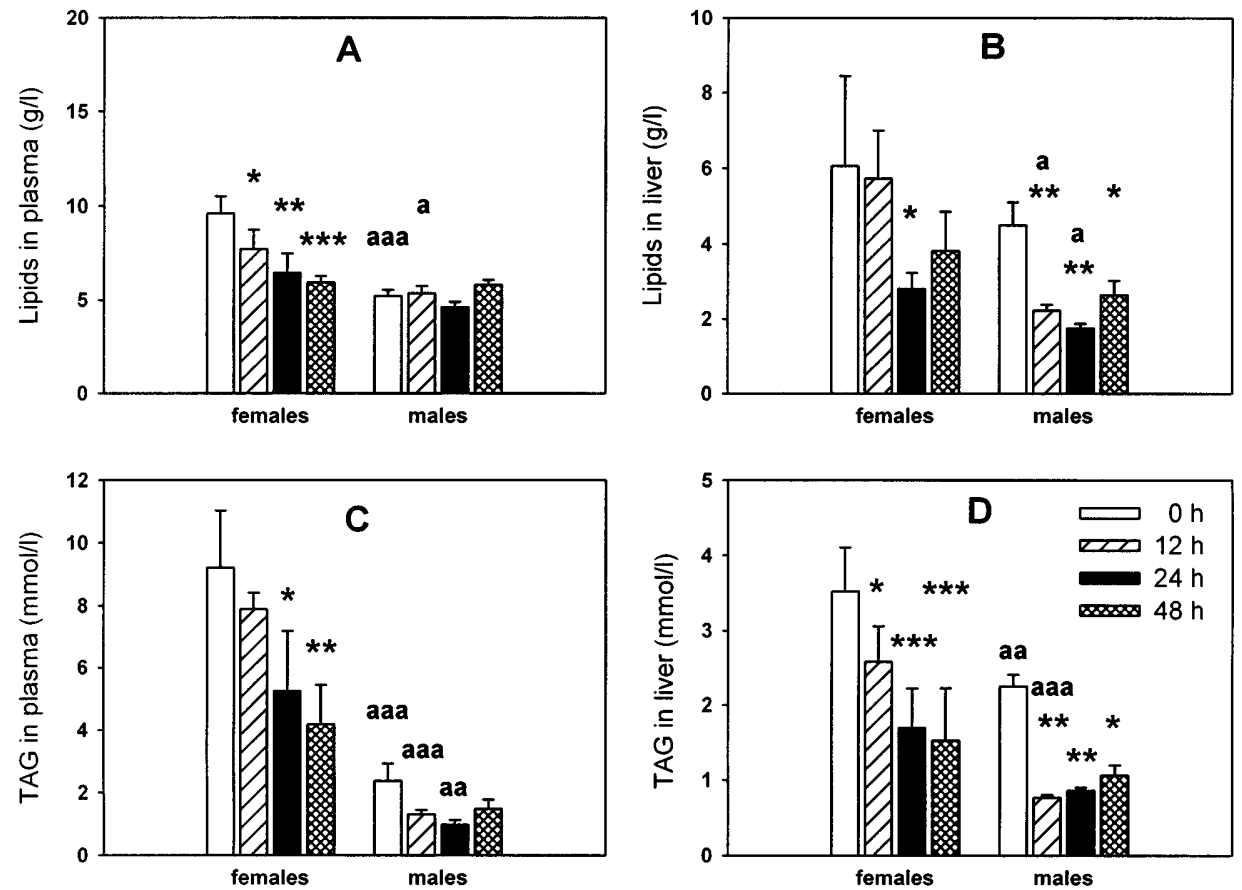

Fig.1. The content of total lipids in plasma (A), liver (B) and the concentration of triacylglycerols (TAG) in plasma (C), liver (D) of adult Japanese quail after 12, 24 and $48 \mathrm{~h}$ fasting. Data are means \pm S.E.M., $\mathrm{n}=5$, $* * * P<0.001$, ** $P<0.01, * P<0.05$ vs 0 time of starvation in one sex, aaa $P<0.001,{ }^{\text {aa }} P<0.01$, ${ }^{\text {a }} P<0.05$ males vs females in the same time of fasting.

possibly by IGF-I as well (McMurtry et al. 1997). Unlike in most mammals, no observable differences in plasma glucose were found in male 3-week-old chickens that were starved for 24 or $48 \mathrm{~h}$ in comparison with ad libitum fed birds (Evock-Clover et al. 2002). In the present study, short-term fasting indicated a general decrease (ANOVA, $P<0.05$ ) of glucose concentrations in plasma of adult birds (Table 2). Concentrations of plasma glucose exhibited a trend of return to initial values in both sexes after $48 \mathrm{~h}$ of fasting. The present results are in agreement with previous observations that blood glucose levels remain unchanged in quail fasted for 48, $72 \mathrm{~h}$ or longer (Didier et al. 1983; Sartori et al. 1995). The decrease of the glucose content in female and male liver was significant after $12 \mathrm{~h}(P<$ 0.05 and 0.001$), 24 \mathrm{~h}(P<0.05$ and 0.01$)$ and $48 \mathrm{~h}$ of fasting in males $(P<0.05)$. After 48 $\mathrm{h}$ of fasting, content of glucose in the liver was aproached to starting levels in females (Table 2). Normalization of plasma and liver glucose concentrations results probably from an increase in gluconeogenesis and a decrease in glucose utilization after a certain short-term fasting.

Food deprivation is associated with lowered nutrient absorption and decreased intestinal function that result from lowered activity of many absorbtive enzymes (Henry et al. 1997). Alkaline phosphatase (AP) which is functionally involved in nutrient absorption and transport of long-chain fatty acids in intestinal mucosa, markedly decreases its activity after a short period (3-6 d) of food deprivation in rat (Holt and Kotler 1987; Kaur et al. 1996; Raček et al. 2001). In the present study, the activity of AP increased progressively with time of fasting $(P<0.05-0.001)$ in females of Japanese quail. In males, plasma AP activity was 

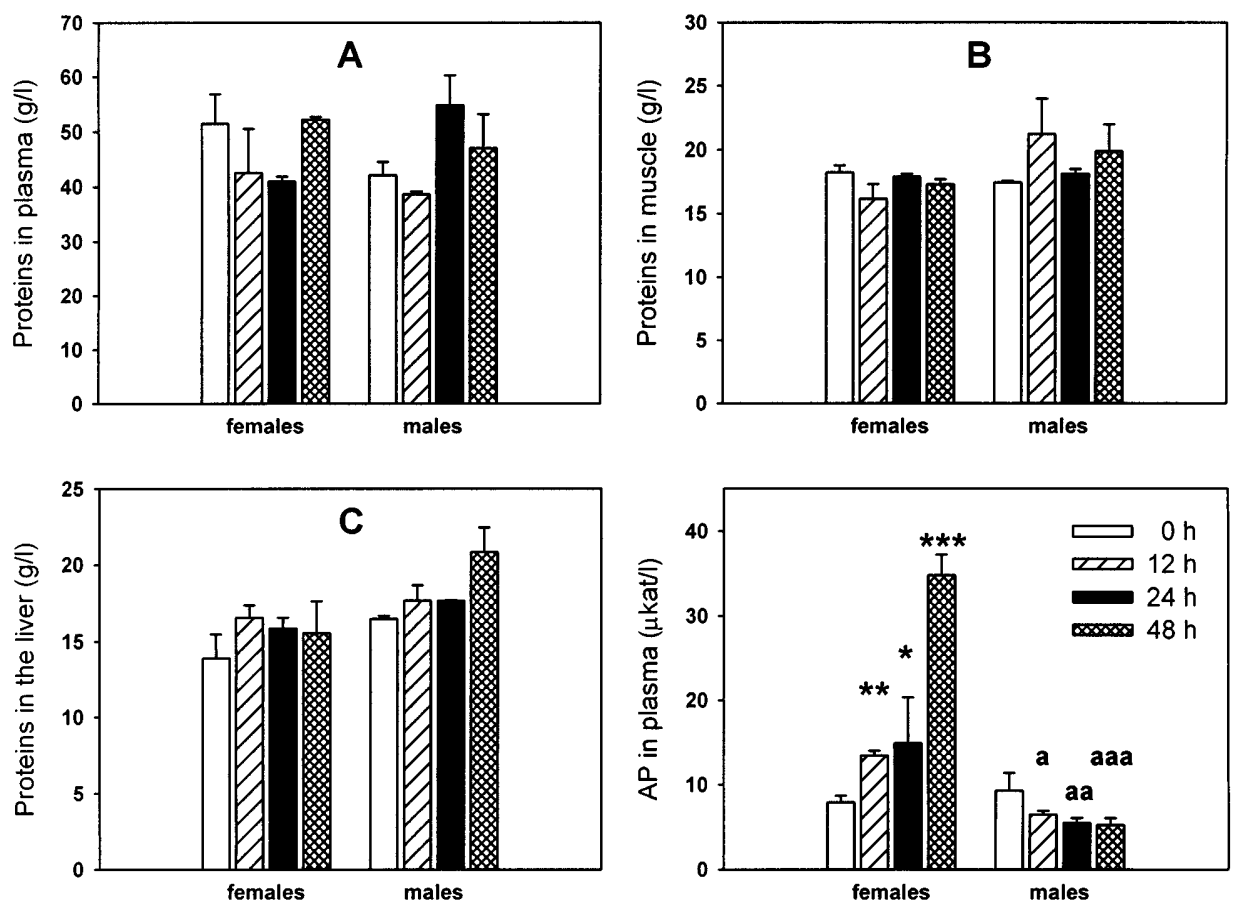

Fig.2. The protein content in plasma (A), liver (B), breast muscle (C) and the activity of alkaline phosphatase (D) in plasma of adult Japanese quail after 12,24 and $48 \mathrm{~h}$ fasting. Data are means \pm S.E.M. $\mathrm{n}=5$, *** $P<0.001, * * P$ $<0.01$, $* P<0.05$ vs 0 time of starvation in one sex. ${ }^{\text {aaa }} P<0.001$, aa $P<0.01$, ${ }^{\text {a }} P<0.05$ males vs females in the same time of fasting.

not significantly changed but it showed trend decrease levels after fasting. This sex difference was highly significant at all tims of fasting $(P<0.05-0.001)$. Our results are in agreement with the data of Hocking et al. (2001) who found an increased AP activity in plasma of female broiler breeders during a food-restricted period. There are no data about AP activity in starved males. In birds, AP plays an important role also in mobilization of calcium in organism from feed mainly during the intensive growth phase and egg laying. The increase in AP activity is an important mechanism to increase blood calcium concentrations during starvation in females in which calcium stores are necessary for shell production.

In summary, the short-term fasting affected mainly lipid metabolism of adult Japanese quail of both sexes. The fasting was characterized by intensive mobilization of lipids, triacylglycerols and hepatic glucose. Great sex differences were detected in content of total lipids, triacylglycerols and activity of alkaline phosphatase in plasma.

\section{Porovnanie účinku krátkodobého hladovania na vybrané fyziologické funkcie dospelých samcov a samíc prepelice japonskej}

Sledovali sme vplyv krátkodobého $(0,12,24$ a 48 h) hladovania na koncentráciu leptínu a alkalickej fosfatázy v plazme a na niektoré parametre tukového metabolizmu, bielkoviny a glukózu u oboch pohlaví dospelej japonskej prepelice. Vplyv hladovania sa prejavil znížením koncentácie glukózy v pečeni samičiek $(P<0.05)$ a samcov $(P<0.05-0.001)$ ako aj znížením celkových lipidov v plazme samičiek $(P<0.05-0.001)$ a v pečeni samičiek 
$(P<0.05)$ a samcov $(P<0.05-0.01)$. Triacylglyceroly boli znížené v plazme samičiek $(P<$ $0.05-0.01)$ a v pečeni samičiek $(P<0.05$ a 0.001$)$ a samcov $(P<0.05-0.01)$. Pohlavný dimorfizmus sa prejavil počas hladu $\mathrm{v}$ hmotnosti pečene počas celého sledovaného obdobia $(P<0.05-0.01)$, rôznou zmenou koncentrácie celkových lipidov v plazme $(P<0.05$ a 0.001$)$ a pečeni $(P<0.05)$. Signifikantný rozdiel medzi pohlaviami bol zaznamenaný v koncentrácii triacylglycerolov v plazme a pečeni $(P<0.01-0.001)$ dospelých vtákov. Pohlavné rozdiely sme zistili tiež v aktivite alkalickej fosfatázy v plazme $(P<0.05-0.001)$. Zatialčo u samcov sme nezistili žiadne zmeny, u samíc bola aktivita alkalickej fosfatázy zvýšená $(P<0.05-0.001)$ počas celého obdobia hladu. Koncentrácia leptínu v plazme, znáška vajec, hmotnosṫ testes, a obsah bielkovín v plazme, pečeni a v prsnom svale neboli hladovkou ovplyvnené. Môžeme teda konštatovat, že krátkodobá hladovka ovplyvnila predovšetkým tukový metabolizmus dospelých vtákov.

\section{Acknowledgements}

These experiments were supported by grants from Slovak Grant Agency for Science VEGA (No 2/1015/01; 2/8208/01) and Science and Technology Assistance Agency (APVT /51016502).

\section{References}

ASHWELL, CHM, CZERWINSKI, SM, BROCHT, DM, MCMURTRY, JP 1999: Hormonal regulation of leptin expression in broiler chickens. Am J Physiol 276: R226-R232

BANKS, WA, LEBEL, CP 2002 : Strategies for the delivery of leptin to the CNS. J Drug Targeting 10: 297-308

BODEN, G, CHEN, X, MOZZOLI, M 1996: Effect of fasting on serum leptin in normal human subjects. J Clin Endocrinol Metab 81: 265-275

BOSWELL, T, LI, Q, TAKEUCHI, S 2002: Neurons expressing neuropeptide Y mRNA in infundi-bular hypothalamus of japanese quail are activated by fasting and co-express agouti-related protein mRNA. Mol Brain Res 100: $31-42$

BUYSE, J, JANSSENS, KA, VAN DER GEYTEN, S, VAN AS, P, DECUYPERE, E, DARRAS, VM 2002: Preand postprandial changes in plasma hormone and metabolite levels and hepatic deiodinase activities in meal-fed broiler chickens. Brit J Nutrition 88: 641-653

DENBOW, DM, MEADE, S, ROBERTSON, A, MCMURTRY, JP, RICHARDS, M, ASHWELL, CH 2000: Leptin-induced decrease in food intake in chickens. Physiol Behav 69: 359-362

DIDIER, R, RÉMESY, C, DENIGNÉ, C 1983: Changes in glucose and lipid metabolism in starved or starved-refed Japanese quail (Coturnix coturnix japonica) in relation to fine structure of liver cells. Comp Biochem Physiol 74: $839-848$

DRIDI, S, WILLIAMS, J, BRUGGEMAN, V, ONAGBESAN, M, RAVER, N, DECUYPERE, E, DJIANE, J, GERTLER, A, TAOUIS, M 2000: A chicken leptin-specific radioimmunoassay. Domest Anim Endocrinol 18: 325-335

EVOCK-CLOVER, CHM, POCH, SM, RICHARDS, MP, ASHWELL, CHM, MCMURTRY, JP 2002: Expression of an uncoupling protein gene homolog in chickens. Comp Biochem Physiol, part A, 133: $345-358$

GOODMAN, MN, RUDERMAN, NB 1980: Starvation in the rat II. Effect of age and obesity on protein sparing and fuel metabolism. Am J Physiol 239: E277-E286

HENRY, CJ, PAYNE, PR, GHUSAIN-CHOUERI, A 1997: Relationship between tissue mobilisation and storage in the rat. Br J Nutr 78: 131-141

HOCKING, PM, MAXWELL, MH, ROBERTSON, GW, MITCHELL, MA 2001:Welfare Assessment of modified rearing programmes for broiler breeders. Brit Poult Sci 42: 424-432

HOLT, PR, KOTLER, DP 1987: Adaptive changes of intestinal enzymes to nutritional intake in the aging rat. Gastroenterology 93: 295-300

KAUR, M, KAUR, J, OJHA, S, MAHMOOD, A 1996: Dietary fat effects on brush border membrane composition and enzyme activities in rat intestine.Ann Nutr Metab 40: 269-276

KOBAYASHI, M, ISHII, S 2002: Effects of starvation on gonadotropin and thyrotropin Subunit mRNA levels and plasma hormone levels in the male Japanese quail (Coturnix coturnix japonica). Zool Sci 19: 331-342

LACY, MP, VAN KREY, HP, SKEWES, PA, DENBOW, DM 1986: Food intake in the domestic fowl: effect of intrahepatic lipid and amino acid infusions. Physiol Behav 36: 533-538

LE MAHO, Y, VU VAN KHA, H, KOUBI, H, DEWASMES, G, GIRARD, J, FERRI, P, CAGNARD, M 1981: Body composition, energy expediture and plasma metabolites in long-term fasting geese. Am J Physiol 241: $342-354$

LEPKOVSKY, S 1983: Feeding controls in chickens. In: Ookawa, T: The brain and behavior of the fowl. Todyo: Japan Scientific Press, pp. 171-184

LOWRY, OH, RESEBROUGH, NJ, FARR, AL, RANDALL, RJ 1951: Protein measurement with the folin phenol reagent. J Biol Chem 193: 265-275 
MAFFEI, M, HALAAS, J, RAVUSSIN, E 1995: Leptin levels in human and rodent: measurement of plasma leptin and of RNA in obese and weight-reduced subjects.Nat Med 1: 1155-1161

MARINO, M, PALLOTTINI, V, DÉRAMO, C, CAVALLINI, G, BERGAMINI, E, TRENTALANCE, A 2002: Age-related changes of cholesterol and dolichol biosynthesis in rat liver. Mechanisms of ageing and development 123: 1183-1189

MCMURTRY, JP, FRANCIS, GL, UPTON, FZ, ROSSELOT, G, BROCHT, DM 1997: Insulin-like growth factors in poultry. Domes Anim Endocrinol 14: 199-229

RAČEK, L, LENHARDT, L, MOZEŠ, Š 2001: Effect of fasting and refeeding on duodenal alkaline phosphatase activity in monosodium glutamate obese rats. Physiol Res 50: 365-372

SALADIN, R, DE-VOS, P, GUERRE-MILLO, M, LETURGE, A 1995: Transient increase in obese gene expression after food intake or insulin administration. Nature 377: 527-529

SARTORI, DRS, MIGLIORINI, RH, VEIGA, JAS, MOURA, JL, KETTELHUT, IC, LINDER, C 1995: Metabolic adaptations induced by long-term fasting in quails. Com Biochem Physiol 111A: 487-493

SATO, K, NISHIDA, M, TAKAHASHI, T, AKIBA, Y 2000: Nutritional regulation of leptin expression in adipose tissues of broiler chickens.XXI Montreal: Worlds Poultry Congress, p.27

SAUDEK, CD, FELIG, P 1976: The metabolic events of starvation. Am J Med 60: 117-126 